\title{
A Case Study of a Successful Multicultural Project: CCEP and the Infusion of Internationalization across the University
}

\author{
Liangmei Bao and Mark Steven Ferrara \\ State University of New York, Oneonta
}

U. S. A.

Globalization has resulted in the call for greater diversity and multiculturalism in higher education. In order to achieve its stated goal of preparing students for "responsible global citizenship," one master's university ${ }^{1}$ has adopted an infusion model of internationalization. This study examines how the university's Chinese Cultural Exchange Program (CCEP) contributed to those campus efforts to enhance multicultural or global awareness, specifically in regards to faculty and student exchanges.

The Chinese Cultural Exchange Program (CCEP)

The Role of Faculty in CCEP

Multiculturalism and the Development of the Teaching Program in China

Limitations and Challenges Faced by CCEP

Endnote

References

Globalization has resulted in the flow of economy, knowledge, information, belief systems, peoples, ideas, and values across borders (Kaplinsky, 2005). While U.S. higher education has been responding to this movement for some time, it has become a prevailing trend only in recent years. According to Green, Luu, and Burris (2008), a "substantial proportion of master's colleges and universities had policies and practices that supported internationalization" and have "made important gains in internationalization since 2001" (p. xiii). These gains include greater internationalization in mission statements, requiring some form of internationally focused learning and coursework emphasizing international issues, a greater emphasis on foreign language learning, and good faculty support for professional opportunities to enhance their international skills and knowledge (Green, Luu, \& Burris, 2008). Because the civic mandate of education is to "develop in students the deepest knowledge base and the highest degree of critical independence possible to undergird informed, socially responsible judgments as voters, parents, consumers, and professionals" (Stoddard \& Cornwell, 2003, p. 44), American colleges and universities have striven to grant opportunities for student immersion in other cultures and to facilitate self-knowledge as these students learn from people with different values, traditions, languages, and perspectives.

Despite this trend toward internationalization, American students continue to be known for their ignorance of geography, the history of those outside of the West, foreign languages, and the events occurring in distant countries (Stoddard 
\& Cornwell, 2003). The reality in U.S. higher education is that most universities and colleges either focus efforts to internationalize on a few majors in international fields of studies (such as international relations, international business, and foreign languages) thus affecting only a small percentage of students, or on general education courses that can be large in size with only superficial connections to international experience (Skidmore, Marston, \& Olson, 2005). This lack of international experience among U.S. college students will remain a challenge in engaging students and building a strong sense of multiculturalism and diversity by focusing efforts only on select courses or programs. In some cases, while opportunities for international learning do exist on many campuses, disseminating that information to students can be challenging as well (Green, 2005).

Given this trend, a private university in the Midwest with a total enrolment about 5,600 students (3,200 undergraduates) now includes in its mission statement the preparation of students for "responsible global citizenship." In order to achieve this goal, the university has adopted an infusion model of internationalization (Skidmore, Marston, \& Olson, 2005). By infusion, we mean the integration of internationalization not only across the curriculum but also through the structures of the university (which include faculty and professional programs and offices) in order to create a campus culture capable of competently engaging the processes of globalization. By Internationalization, we mean a process that integrates an international or intercultural dimension into the teaching, research purpose, and service functions of the institution (Knight, 1994). The present study describes the success story of the Chinese Cultural Exchange Program (CCEP) as part of a campus-wide effort to enhance internationalization.

\section{The Chinese Cultural Exchange Program (CCEP)}

The Chinese Cultural Exchange Program, created in 2004, has provided faculty development opportunities, placed graduates in teaching positions at secondary schools and universities in China, and organized China-related activities on campus that are open to the community. The Chinese Cultural Exchange Program's contribution to the infusion of internationalization includes the exchange of faculty, students, and graduates between the university and educational institutions in China. Between 2004 and 2008, CCEP trained and placed 84 graduates in English language teaching positions at our partner institutions in China. Over the same four-year timeframe, 20 faculty members also taught in China for the periods of one to three weeks with CCEP, and CCEP continually hosted visiting scholars from China. These visiting scholars contributed to campus internationalization by giving lectures, providing guidance to faculty and graduates teaching in China, and helping to strengthen relationships with the CCEP partner institutions from which they come. CCEP has also assisted with the development of joint degree programs with Hebei 
Normal University (河北师范大学) and Southwest University of Political Science and Law (西南政法大学) to further facilitate the exchange of faculty and students. CCEP now works with more than 10 institutions in China.

Between 1978 and 2003, a total of 700,200 Chinese citizens travelled abroad to study, with a large percentage of those studying in the United States. In fact, the United States continues to receive the largest number of international students of any country; even with the decline caused by 9/11 (Li, 2005) nearly 1.2 million Chinese were enrolled in U.S. higher education (Chin, 2003). By the turn of the $21^{\text {st }}$ century, the United States became the number one choice for Chinese students, as well as for students from other Asian countries (Hawkins \& Cummings, 2000). In 2003 alone, together with Taiwan, China sent total of 92,774 students to the United States (64,757 from Mainland China and 28,017 from Taiwan), the largest number of students and scholars from a single country (Chin, 2003).

\section{The Role of Faculty in CCEP}

Greater faculty awareness of international education has been shown to increase student participation. As Kelleher (1996) points out, to develop students' international knowledge and skills, faculty must first develop their own. The development of international education includes hiring international faculty, or faculty with international expertise, and re-educating existing faculty. Indeed, faculty's competence and commitment, with the assistance of the institutional leadership, significantly affect the degree of campus internationalization (Harari, 1981). Faculty help to internationalize the campus by offering the general education program, academic disciplines, and courses; encouraging students to attend international events; facilitating classroom interaction between international and domestic students; and generally shaping an internationalized campus culture (Green \& Olson, 2003). Formal exit interviews conducted with CCEP faculty participants demonstrated that they contributed to campus internationalization efforts in many ways: the integration of international elements into curriculum, the creation of new classes, the development of an international focus in faculty research, and increased service contributions to multicultural student organizations and academic committees (Bao, 2009).

To facilitate international faculty development, CCEP funds six faculty members per year to lecture in China. Between 2004 and 2008, CCEP faculty participants included individuals from five different schools (Arts and Science, Education, Pharmacy, Business, and Law) as well as the library. Based on the needs of the Chinese host schools and faculty members' areas of expertise, faculty either taught a short course or delivered series of lectures for one to three weeks. Because of the differences in academic calendars, faculty members were able to visit China in May and June without interrupting their regular teaching obligations in the United States (the Chinese academic year ends in July). Only 
two of the 20 faculty members had visited China before as tourists; it was the first time for the rest of the faculty participants to travel or teach in China.

Faculty members participating in CCEP are encouraged to use innovative instructional strategies, both in China and upon their return to the United States, which incorporate experiential learning into an effort to internationalize the curricula. For example, teaching in China allowed one participant, who used to offer a class on prejudice and discrimination in cases of genocide, an opportunity to grow both academically and spiritually and to develop a new course never offered before at the university. As she explained:

What happened on my trip in China was that I spent a lot of time talking to students. I went to a number of Buddhist and Daoist temples, and spent time sitting, mediating, [and] thinking. As a result, when I got home, I began to find material from China that was translated, and for the three years since I have been back from China, l've twice led student and community members for summer study seminars. (Bao, 2009)

Because of the limited study abroad opportunities at this Midwestern university, CCEP provides an avenue of experiential learning to both faculty and graduates who teach in China, as well as opportunities for Chinese students and visiting scholars to study at the university. The visiting Chinese students worked for the university's Chinese language acquisition program, contributed to the international student association, and brought unique perspectives to courses with an international focus.

While experiential learning is often advocated for students, the experience of travelling and teaching in the Far East also enriches faculty members' personal worldviews and generates greater interest in international education among faculty colleagues and students. Many faculty members who participated in CCEP have been able to integrate their newfound knowledge into their teaching since they returned. One CCEP faculty participant from the Culture and Society department commented, "I took thousands of pictures....and I brought many things to my class." When he taught the cultural geography of China previously, it was based on book learning. Suddenly, it was "based on my personal experience. So naturally the emphasis of presenting [the material] was so different. It brought a lot of things to my class, to my teaching." Likewise, the opportunity to teach in China transformed the courses of a CCEP participant in Fine Arts: "When I came back from China," he remarked, "a year later I revised all of my classes," based on the observation that art students in China had a better command of foundational painting skills than did his American students (Bao, 2009). These experiences echo Garson's (2005) finding that faculty members returning from overseas visits become more actively involved with international students taking courses at their college and tend to integrate intercultural understanding into their teaching practices. As "teachers are the agents through which knowledge and skills are communicated and rules of conduct enforced" (Dewey, 1938/1997), it is not surprising to see the connection between faculty's experiences in China and the interests of students in international education generated through classroom interaction. 
In this regard, clearly faculty who participated in CCEP developed an increased global awareness, engaged with students and other international programs, and helped to infuse internationalization across the university. For example, another faculty participant in sociology remarks, "China is certainly the forefront of my [American students'] consciousnesses when they think about globalization," and as a result of her trip to China she has been able to "create some very powerful lectures for students at [my university]." She asked students in an earlier class to define globalization after telling them how students "in St. Petersburg talked about it, how students in China talked about it, how students at [the college] where I taught before talked about it, and it really gives a strong example how social location affects the way people see the world." A CCEP faculty participant from the School of Education now teaches a course called "Ethical Tensions in Global Urbanization," which resulted from the research he did in China (Bao, 2009). Research indicates that the less international education faculty gain, the lower are the success rates in terms of campus internationalization at higher education institutions (Green \& Olson, 2003). A core of committed faculty, therefore, is essential to create and sustain that transformation, and only when a substantial number of faculty members actively participate can the institution provide students with diverse international learning opportunities in a fully integrated educational process.

\section{Multiculturalism and the Development of the Teaching Program in China}

Hayward (2000) notes that less than three percent of U.S. students participate in study abroad while the majority of undergraduates and college graduates are not well prepared for either the rigorous international competitiveness or the roles of informed citizens in a highly unpredictable world. Studies show that students who have an international education are more likely to realize an international career, increase their marketability, better understand U.S. and foreign business cultures, gain an understanding of the global market place, help to improve international relations, and finally better understand their own culture as well as those that are different (Hinkelman, 2001). Teaching in China with CCEP provides an extended experiential learning opportunity for graduate participants. While only a small percentage of graduating seniors take advantage of the CCEP program, many participants share their teaching experiences in China through blogs, encourage potential future participants at the university, and return to contribute to the CCEP graduate training seminar. Stoddard and Cornwell (2003) note:

Through the struggle to survive and find a workable life overseas, those who have to give up a great deal (such as the material comforts of the developed world) often gain an enlarged sense of consciousness from their struggles and develop a greater sense of compassion for the sufferings of others. (p. 47) 
As part of their continuing education, living and teaching in a rapidly developing country like China provides an opportunity for CCEP graduate participants to get out of their comfort zones and to develop both personally and professionally.

Research supports the importance that CCEP places on providing crosscultural counselling and assistance for college students studying overseas as they struggle with a new culture, social life, and health care system (Tyler, 2000). Because the great majority of our graduate participants have never visited China before, we found it is essential to build a support system for them by cultivating and maintaining excellent institution-to-institution relations. Moreover, CCEP generally places at least two graduates at each partner Chinese school, and a university delegation, led by the provost and including the director and assistant director of CCEP, visits the graduates in China once a year. Often these trips combine scheduled meetings with partner institutes about new program development.

Student feedback reinforces the importance of the training and support CCEP provides. One of the graduates remarked about the value of participation in an interview for our alumni magazine:

Learning those basic skills really helped me when I got to China. Also, learning about the culture was very helpful because it made things a bit less shocking when I got here, and learning the history helped me understand why things are as they are today" (Olson, 2007).

Another CCEP participant from the 2004-05 academic year also wrote about her positive experience:

[The] Chinese Cultural Exchange Program was the single most significant experience of my higher education. I not only plan to visit and possibly live in China again in the future, but this has proven to me that I am capable of doing the same thing in any part of the world. In short, my worldview is immeasurably broader today than it was on the day of my graduation.

Similarly a CCEP graduate from 2005-06 sent the following message to encourage his peers to participate in the program:

Through the Chinese Culture Exchange Program you can find experiences that open your eyes to the other side of the world. Living, learning, and teaching in a foreign country will lead you to a better understanding of yourself and of the people you share this world with.

Such transformation of attitude and perspective has been recognized by scholars like Hadis (2005) who notes that college students "show positive changes" after returning from studying abroad, bring back with them "an enhanced concern about international affairs... and [become] more mature, selfaware, and independent" ( $p .3)$. The CCEP graduate program provides cocurricular opportunities for international experience, and participants brought an international perspective back to the university, the classroom, and their peers, thereby contributing to a culture of internationalization on campus. Of course, unlike faculty who bring the tangible benefits of multicultural exchange back to 
the university over many years, CCEP graduate participants do move on-and it is hoped as better global citizens. Yet, while in China they share their experiences through campus publications, blogging, and personal correspondences with current students and thereby infuse their experiences on campus.

\section{Limitations and Challenges Faced by CCEP}

CCEP is in its fifth year and has grown from 9 graduate participants in 2004 to 23 in 2008 and from one Chinese visiting scholar in 2005 to four on campus in 2008. Every year more faculty members apply to teach in China than the CCEP budget allows. Moreover, the 2007 three-week-long summer study seminar to China had 23 undergraduate and community participants. Chinese language students enrolled in the university Language Acquisition Program have also increased from four in 2002 to nine in 2007, and these students are often interested in teaching overseas with CCEP after graduation. Yet, there are limits to what CCEP can do. One of the biggest limitations we face is that the university does not offer traditional undergraduate study abroad in China but instead uses outside providers processed through International Programs and Services.

Another limitation is financial. Some readers might incorrectly assume that CCEP receives significant financial assistance from the university. In fact, CCEP has accomplished its goals on an annual operating budget generated by training and placement fees from the graduate teaching program in China (currently $\$ 1,000$ per year per participant). In addition, all visiting Chinese scholars who came to this American university from partner institutions have been funded by the Chinese government through a body known as the Chinese Scholarship Council (中国留学基金委), which limits the ability of CCEP to select candidates. Even the CCEP faculty program only covers the cost of the flight to China and the visa fee. The host institution provides housing to faculty members while they teach (a common arrangement in East Asia). Indeed, CCEP may be a textbook case of how to start a China program for the purpose of campus internationalization on a shoe-string budget.

In addition, the growing enrollment in the CCEP graduate program would also increase the need for finding and maintaining excellent placements at institutions of repute in China at a time when more foreign teachers are competing for these positions. Moreover, there exists a need for a CCEP staff member to be stationed in China to help coordinate the graduate program and oversee dual degree programs with Southwest University of Political Science and Law in Chongqing and Hebei Normal University in Shijiazhuang. At the moment, CCEP is directed solely from the United States, a situation that has obvious limitations and presents many challenges.

No expert or guru can formulate a definitively successful approach to internationalizing an academic institution (Sutter et al., 1992). So, while this study 
has explored how faculty and graduate teaching experiences in China have contributed to the infusion of campus internationalization at one mid-western university, the findings of the study may not be generalizable and replicable as different variables affect international exchange programs. These variables, which ultimately affect the quality and success of an international educational program, include the unique culture of each institution, the qualifications of the participants, the geographical setting of the school, the amount of administrative support the international program receives, and the relationship with its partner institutions abroad.

Nevertheless, it is clear that the higher the level of faculty involvement in international activities and the more students who participate in international activities, the more successful the campus internationalization efforts will be (Green, 2005). The overall exchange of faculty and students between China and the United States has been growing steadily, with the sole exception of the students' demonstration at Tiananmen Square in 1989, which nearly halted exchanges with American universities (He, 1991). As long as both governments work to continue a favorable political relationship and support academic exchanges, programs like CCEP will continue to flourish on U.S. campuses, helping to facilitate understanding between cultures and contributing substantially to efforts to infuse internationalization across campus.

\section{Endnote}

1. The Carnegie Foundation classification puts this private university with three doctoral programs in the category of "master's universities."

\section{References}

Bao, L. (2009). Faculty development and campus internationalization: A case study. Unpublished doctoral dissertation, Drake University, lowa.

Chin, H. K. (2003). Open doors: Report on international educational exchange. New York: Institute of International Education.

Dewey, J. (1938/1997). Experience and education. New York: Touchstone. (Reprinted from Kappa Delda Pi).

Garson, B. (2005). Teaching abroad: A cross-cultural journey. Journal of Education for Business, 80(6), 322-327.

Green, M. F., Luu, D., \& Burris, B. (2008). Mapping internationalization on U.S. campuses. Washington, DC: American Council on Education. 
Green, M. (2005). Internationalization in U.S. higher education: The student perspective. Washington, DC: American Council on Education.

Green, M. F., \& Olson, C. (2003). Internationalizing the campus: A user's guide. Washington, DC: American Council on Education.

Hadis, B. F. (2005). Gauging the impact of study abroad: How to overcome the limitations of a single-cell design. Assessment \& Evaluation in Higher Education, 30(1), 3-19.

Harari, M. (1981). Internationalizing the curriculum and the campus: Guidelines for AASCU institutions. Washington, DC: American Association of State Colleges and Universities.

Hawkins, J. N., \& Cummings, W. K. (2000). Transnational competence: Rethinking the U.S. - Japan educational relationship. New York: State University of New York Press.

Hayward, F. M. (2000). Preliminary status report 2000: Internationalization of U.S. higher education. Washington, DC: American Council on Education.

$\mathrm{He}$, Li (1991). U.S.-China education exchanges past, present, and future perspectives. Unpublished doctoral dissertation, Cornell University, New York.

Hinkelman, J. M. (2001, August). Preparing students for the international Marketplace: International work programs. Paper presented at the Annual Meeting of the American Psychological Association, San Francisco, CA.

Kaplinsky, R. (2005). Globalization, poverty and inequality. Malen, MA: Polity Press.

Kelleher, A. (1996). Learning from success: Campus case studies in international program development. New York: Peter Lang Publishing.

Knight, J. (1994). Internationalization: Elements and checkpoints (Research Monograph No. 7). Ottawa, Canada: Canadian Bureau for International Education.

Li, C. (2005). Bridging minds across the Pacific: U.S.-China educational exchanges, 1978-2003. Lanham, MD: Lexington Books.

Olson, T. T. (2007, July). Teach in China program is a success with Drake graduates. On Campus Newsletter. Retrieved July 28, 2007, from 
http://www.drake.edu/news/dbletter/oncampus/archive.php?newsletter=98 \&article $=1870$

Skidmore, D., Marston, J., \& Olson, G. (2005). An infusion approach to internationalization: Drake University as a case study. Frontiers: The Interdisciplinary Journal of Study Abroad, 11, 187-203.

Stoddard, E., \& Cornwell, G. (2003). Peripheral visions. Liberal Education, 89(3), 44-51.

Sutter, R. L., Fang, F., Floyd, D., Holder, C. R., Munshower, C. B., Roberts, H., \& Robinson, B. (Eds.). (1992). Internationalizing the California State University. Long Beach, CA: CSU Institute for Teaching and Learning.

Tyler, P. (2000). A great wall: Six presidents and China. New York: Public Affairs. 